\title{
ANALYZING ISLAMIC ARCHITECTURE VISUAL QUALITY IN BUSHEHR CITY; CASE STUDY: RELIGIOUS SPACE KAZERUNI BARHAH (HOSSEINIYE)
}

\author{
Mehran Alalhesabi \\ Department of Urban Studies, Iran University of Science \\ \& Technology, Tehran, Iran \\ e-mail: alalhesabi@iust.ac.ir \\ Seyyed Bagher Hosseini \\ Department of Architecture, Iran University of Science \\ $\&$ Technology, Tehran, Iran \\ e-mail: hosseini@iust.ac.ir \\ Fatemeh Nassabi \\ Ph.D Candidate at the Department of Architecture, Iran \\ University of Science \& Technology, Tehran, Iran \\ e-mail: fnassabi@yahoo.com \\ Bahram Saleh Sedhpour \\ Shahid Rajaei University, E.D.U. Tehran, Iran
}

\begin{abstract}
Islamic architecture can be studied from different aspects. This paper introduces a religious place in Bushehr city of Iran, a Bahrah or Hosseiniye that is used in especial religious ceremony and was built a century ago and after recent renovations is still in use and applicable. The research tries to quantify and analyze its visual quality as an important quality in the built environment with a tool called isovist in Syntax 2D software. In this study isovist indexes of six different spaces have been evaluated in this. The research shows interesting findings of spatial form and location and its visibility; for example it shows that spaces with circulation role have more visibility also spaces of the higher floor show higher visibility than the ground floor.
\end{abstract}

Keywords: Visibility analysis, Syntax2D, religious space, isovist, Barhah

\begin{abstract}
Abstrak
Arsitektur Islam dapat distudi dari berbagai aspek. Tulisan ini memperkenalkan sebuah tempat religius di kota Bushehr di Iran, sebuah Bahrah atau Hosseiniye yang digunakan dalam upacara keagamaan dan dibangun seabad yang lalu, dan setelah renovasi baru-baru ini masih digunakan dan dimanfaatkan. Penelitian ini mencoba untuk melakukan quantifikasi dan menganalisis kualitas visualnya sebagai sebuah kualitas yang penting di dalam lingkungan binaan dengan alat yang disebut isovist dalam software Syntax 2D. Dalam studi ini indeks-indeks isovist dari enam ruang yang berbeda telah dievaluasi. Penelitian ini menunjukkan temuan yang menarik dari bentuk spasial dan lokasi dan visibilitasnya. Salah satunya adalah penelitian ini menemukan bahwa ruang-ruang yang berperan sebagai sirkulasi memiliki visibilitas yang lebih tinggi. Demikian pula dengan ruang-ruang di lantai atas, memiliki visibilitas yang lebih tinggi daripada ruang-ruang di lantai dasar.
\end{abstract}

Kata kunci: Syntax2D, ruang religius, isovist, Barhah, analisis visibilitas

\section{Introduction}

Islamic architecture can be seen in Iran and the same style is visible in different countries like Iraq, Iran, Afghanistan, Pakistan and Tajikistan. Religious ceremonies took place in different places in Iran like mosques or Hosseiniye. The city of the study is located by the Persian Gulf, Bushehr city at the southern part of Iran with a unique architectural fabric. Having high level of humidity, Bushehr city has different urban and architectural fabric comparing to other cities of Iran. This paper works on one type of Hosseiniye that was used for especial religious ceremony and studies its visual quality as Visibility influence users' perception and spatial behavior. The tool used in this study is isovist that as
Benedikt puts it is "the set of all points visible from a given vantage point in space" ${ }^{\text {. The study examines }}$ isovist in different spaces of the case study. The results of this study show that different spatial configuration lead to various visibilities.

\section{Method}

Using experimental method, this paper is an analysis of isovist properties created at the center of spaces of a case study. Quantifying the visual quality and studying its indexes, this study uses geometric indexes of Benedikt $^{2}$ including area, perimeter, occlusivity, circularity and compactness. Drift index has also been studied that shows isovist longest 
possible line of sight. Circularity is the ratio of the square of the perimeter to area $^{3}$ and shows the spikiness of the isovists. Occlusivity is about the proportion of the perimeter on the solid boundary of the environment, while on the other hand compactness index shows how close the isovists are to a convex space and drift index shows isovists longest possible line of sight.

The analysis can be done by different computer programs like Depthmap, Spatialist, and Syntax2D. In this research Syntax2D has been used, that is "an open source spatial analysis software program developed by the Taubman College of Architecture and Urban Planning at the University of Michigan and is a suit of tools for researchers and practitioners to analyze spatial configuration of buildings and urban space ${ }^{4}$.

\section{Literature Review}

Visibility analysis was first explained by Gibson's psychological theory of direct perception ${ }^{5}$ that is one of the main theoretical foundations to develop visibility analysis. Direct perception regards the relationship between the occupant and the environment, rather than attempting to gain access to the vernacular phenomenological idea of perception. Gibson has further developed his theory of ecological visual perception with the ambient optic array $^{6}$.

Being inspired by his theory, Benedikt described space by 'isovist' that is "the set of all points visible from a given vantage point in space"7. He worked on properties of isovist to describe the environment with quantitative measures. In his view isovist fields are with the ability to "assess some basic spatial qualities of environments whose conscious or unconscious apprehension may guide or underlie 'higher' cognitions and behaviors, and to create a basis for or a contribution to a fuller description of the environment"8.

Visibility analysis defines that the shape and size of the isovist is unique according to geometry and movement of observer. After Benedikt some researchers examined the importance of isovists for spatial perception. Hillier and Hanson's works show that space syntax has used isovist analysis to interpret visual perception. Space syntax is a set of technologies for the analysis of spatial configurations using simple graphs solely consisting of paths and nodes 9 . They introduced visibility relationships into graph analysis of buildings and urban systems as part of the space syntax research agenda and suggested constructing the fewest and longest lines of sight and access in a system that traversed all the convex spaces constituting the system. They called these lines 'axial lines' and by subjecting them different quantifications, they were able to express the nature of circulation paths in terms of lines of sight. The drawback of this method was its dependence on convex spaces, which were not produced totally objectively. "The techniques were developed in the late 1970 in order to analyze interrelations between spatial and social structures. This analytical reduction of space to mere topological mathematical information facilitates the calculation of characteristic values and the quantitative comparison of environments" 10 .

Peponis, Wineman, Rashid, Kim, and Bafna ${ }^{11}$ created measures which defined e-partitions related to axial lines and isovist. Peponis et al. ${ }^{12}$ suggested $\mathrm{m}$-lines and e-lines as a more rigorous way to produce axial lines objectively. Movement lines, or $\mathrm{m}$-lines, represent the minimum path that a moving observer needs to cover so that all surfaces have become visible from at least one point. The set of these lines produce what they called the 'linear visibility map.' Endpoint partition lines, e-lines, create discrete informational stable units of space.

Lynch's work on legibility ${ }^{13}$ and spatial and visual analysis of Conroy and Bafna ${ }^{14}$ were the works which further developed the theory. Turner, Doxa and Penn ${ }^{15}$ worked on visual relationships and locations and the mutual visibility between locations. They have worked on visibility graph analysis that leads to analysis of various positions in the environment by calculating the intervisbility of locations in the environment to better describe geometry and envinmental characteristics. various studies have shown indicators for spatial perceptions, utilizing computational visibility analysis such as isovist and viewshed as the perception's quantifier ${ }^{16}$. Yang et al. worked on Geoffrey Owen in 2004 and his team discussing that, our eyes, or precisely our retina, perceive visual signals from arrays of photon ambient of our position in the environment through process of estimation, and not identification. The retina estimates the 'true' signal transferred by photonic arrays, or ambient optic arrays in Gibson's term ${ }^{17}$, then transmitted them to our brain cortex, collectively generating our visual perception. The estimation process means that human visual perception is never a discreet experience which requires discreet mathematical modeling in order to be examined scientifically, but can be represented by approximated value or model with reasonable accuracy. Any demand for an accurate quantitative representation of human visual perception will be impossible to meet, and thus the values and models in this paper are can be deemed as reasonably adequate for measuring visual perception $^{18}$.

In the context of measuring urban environment, Putra argued that the spatial properties of 'visible space' (in relation with urban and environmental space) can be defined and measured from the 
collective amount of geometric Cartesian space occupied by photon rays or ambient optic arrays reflected by physical surfaces and visually perceivable from a particular vantage point. This definition implies the potential of developing an approach of quantitative visibility analysis in a three dimensional way ${ }^{19}$. Tahar and Brown ${ }^{20}$ studied traditional M'zambite houses using space syntax methodology to analyze visibility and accessibility of domestic spaces. In houses visual fields are related to the need for privacy of the residents.

Other studies focused on examining architects' way of exploring the relationship between visibility and permeability through spatial layering, transparency, the inter-penetration of volumes and the dissolving of boundaries, while some others tried to explicate the role of visibility in manifesting the social logic behind houses ${ }^{21}$.

To analyze the visibility structures a number of computer programs have been introduced. One of them is the Spatialist program developed by Peponis et al in Georgia Tech, in which e-lines have been automatically generated and convex spaces created by them, espaces, colored accordingly. The main problem with using e-space analysis is the quite high number of e-spaces, which makes it hard to makes sense of the data. Another program, which is developed at University College London by Alasdair Turner ${ }^{22}$, is called Depthmap. The program divides any given plan into a grid, whose size can be determined by the user, and enables to generate and examine the visibility graph representing visible connections between different point-locations at the center of each grid. Syntax 2D program, developed by James Turner at the University of Michigan in 2005, is a more recent program that is still under development. It is significant to note that this program is a vector-based program that considers the geometry of the plans and can calculate various measures of the isovist field, such as its area at any given point on the $\mathrm{fly}^{23}$.

Batty $^{24}$ stated that the actual physical morphology of complex urban building and streetscapes cannot best be measured by the geometry itself, but is more likely to be represented by the visual 'objects' or 'visible spaces', which is Gibson's ambient optic array emerging as a result of this geometry. This statement has expressed the basis principle for two- and three dimensional analysis. The impact of visual field or ambient optic array for human perception is already well known, and so it's natural that much effort goes into using, and trying to predict the impact upon visual or spatial perception. Awareness, whether unconscious or articulate, of visual qualities and lines of sight has been part of human activity, settlement building, military defense, hunting, and agriculture since prehistory. It indicates that we should evaluate the potential visual impact of the existing and proposed urban. The term 'visibility' has been used casually by so many disciplines, implying to different meanings that sometimes are not identical or even correlated at all. This is an example of a popular definition of 'visibility': “the ability to view or the viewing quality of an object or scenery which is affected by atmospheric quality." In aviation and navigation, 'visibility' is used to refer to the distance of unimpeded visual range, because of atmospheric factors, as in 'visibility' of 1000 meter. In lighting studies visibility relates with 'glare', or lighting indicators such as 'lux'. Psychological and philosophical meanings of visibility, as implied by the English term 'to see', may imply 'to understand', instead 'to view.' These meanings will not be discussed in this dissertation, although they are relevant factors which contribute to the totality of human visual perception of urban space ${ }^{25}$.

Reviewing the literature of the case study, it shows that there is not a lot of work done on architecture and housing of Bushehr. A group of medical science university of Bushehr accomplished a research on 218 dwellings in cultural-historical fabric of the city based on a questionnaire of social, sanitarian, urban and cultural heritage factors. In his master thesis Darvishi ${ }^{26}$ worked on guidelines and criteria for design of the city hall of Bushehr city, while Parsaii ${ }^{27}$ studied traditional architecture principals in current Bushehr housing design and tried to introduce Bushehr architecture and especially traditional housing role in modern architecture. Nabipur ${ }^{28}$ tried to describe architecture of Bushehr and its aesthetic elements of color and light in his book. Kashuk's book is a study of Bushehr architecture history in subjects of geographical location, social and cultural studies, old fabric of this city and climatic elements, architecture in the old fabric and its elements, the relationship of old fabric of Bushehr and the world architecture and use of architectural and urban principles of old fabric in temporary buildings. This book works on qualitative and quantitative elements of buildings of Bushehr city $^{29}$. Sabatsani's work discusses Bushehr ecologically. In his idea, Changing Bushehr into an Energic city can solve many sustainability problems and he offers a model which responds to $i^{30}$.

The review of literature shows that isovist analysis is a popular way to quantify visual quality of space and because there is not a lot of studies done on Bushehr residential visual quality, the work in this field is of great importance.

\section{Old Fabric of Bushehr}

Bushehr is a city on the southwestern coast of Iran, on the Persian Gulf. It is one of the important seaports of the country and the administrative 
centre of Bushehr province. Bushehr port's architecture has unique historical fabric and its architectural elements are very fine but as time has passed, due to rapid growth of the city this fabric is losing its function ${ }^{31}$. The old town of Bushehr is situated on the northern end of the Bushehr peninsula in the eastern coastal area of the Persian Gulf. It is located at a latitude of $28^{\circ} 59^{\prime} \mathrm{N}$ and longitude of $50^{\circ} 51^{\prime} \mathrm{E}$ and its altitude is $5 \mathrm{~m}$ above mean sea level ${ }^{32}$. The form of the buildings changed from being singlestorey with wind towers which were of the same type found in inland Persian architecture, to multiple story buildings without wind towers, which were a type of coastal Persian Gulf architecture. All buildings had similar façades and even mosques did not have domes and minarets; the lanes became narrower and the buildings had only one entry so they were more defensible ${ }^{33}$.

To maintain indoor and outdoor areas comfortable plenty of shade is provided and external surfaces are painted in light colors to reflect solar radiation. Even heavy walls and roofs exposed to solar radiation for long periods accumulate heat and either conduct it to the interior of the building or reject it during the night to the surroundings, increasing the night heat island effect. Therefore different methods of shading have been used. During summer the sun angle approaches the zenith angle and this demands that horizontal surfaces be shaded, but there is still scope for fixed systems such as overhangs on vertical walls with southerly, easterly and westerly orientations. Specific types of wooden balconies known as shenashirs have been used to protect vertical surfaces. Also very deep balconies are integrated in to buildings wherever possible. Different types of vertical and horizontal wooden shading devices have been used to cover the surfaces. These balconies, shenashirs and shading devices in principle and form are similar to the ones that have been used on the east coast of Africa and in India and on the Arabian Peninsula ports in the Persian Gulf. Figure 14 shows a shenashir in Abushahr ${ }^{34}$. Bushehr port and especially its old fabric have valuable architecture wealth from Afsharid era across the Persian Gulf. Having unique characteristics in urban and architectural structure and also existence of European consulate of Ghajar era, it is an exceptional historic fabric in Iran. Streets are close to each other due to residents' needs and regions hot weather ${ }^{35}$.

One of the characteristics of Bushehr people is their simplicity that is revealed in their architecture too. Spaces and elevations are designed according to their functional role. Even mosques are very simply built and their only difference with the houses is the emphasis on the entrance and there is no sign of domes in this architecture ${ }^{36}$.
A complex of narrow streets that begins from a local square reaches another one and after passing number of squares reaches the sea, creates the old fabric of Bushehr city. This non-geometrical network transfers the sea winds to the city to enter spaces passing through wooden shades of windows called shenashil ${ }^{37}$. The boundaries of old texture of Bushehr city was the Caspian Sea from three sides and it joined the city from its southern part. Harmonious height of buildings, similar openings and windows, wooden shades in white background of the city, has created a unique silhouette. Having the least common walls in the neighbourhood to use the most of air, has divided urban fabric to separated blocks with one or number of dwellings ${ }^{38}$. Old fabric of Bushehr city has experienced changes that led to gradual expansion of the primary core of the city. With the new urban revolution, city growth was shaped in a suburban form and old and historic fabric of the city faced exhaustion. With the people tendency to modern and new construction, old buildings were destructed without care to historic antiquity and disharmonic buildings disregarding old fabric or even their especial climate were replaced by them. On the other hand, low price of rent, low level of life and old buildings led to transfer of people with higher income and their replacement with migrates and low income people and the exhaustion process increased $^{39}$. In 1964 Enghelab Avenue (6 Bahman) divided the fabric into two parts to establish northern- southern access of the fabric.

The distance between commercial zone and port on the east and administrial zone in the southern and northern part of the sea was filled by four residential neighbourhoods, Behbahani, Shanbedi, Dehdashti and Koti (Sheikh Sa'adun). The first three neighbourhoods were located on the eastern half from north to south, while Sheikh Sa'adun was in the western part. Each of them had a strong organizational and structural centre that socialcultural activities were shaped across this role. The main core of these centers was mosques. The structure of neighbourhoods was that much strong that residents had the sense of belonging to them ${ }^{40}$.

In Bushehr city because of being situated by the sea, high level of underground water and humidity, there is no basement and also ground floor plan has a service role with spaces like kitchen and food store while first and second floor have more residential role. Another advantage of upper floor is that air draught is easier in these floors and their windows are kept from pedestrians' view which makes them more private.

Due to high density of the fabric and narrow streets, air movement is difficult, so Taremi and shenashils are connected to interior space and the courtyard acts as a chimney ${ }^{41}$. Although there is a 
central courtyard in the house, it is looking outwards because of the existence of Taremi (temporary seasonal balcony and living room) and shenashil (balcony and a place to benefit desired wind and breeze) which is connected to outside. Taremi or portico is one of the spaces in these houses that are semi open and roofed and in some houses it is with wooden shades to keep privacy of rooms, and is used for night rest. Shenashils are special porticos which much of daily activities take place in them and are very spacious to provide large outdoor living area.

Balconies in Bushehr are larger from other regions and shape important spaces in building. Having fine ventilation and being located in shadow, in hot seasons that its period is almost half a year most daily activities take place in them ${ }^{42}$.

Most buildings are semi inside looking and rooms are situated around central courtyard but their relation with outside is not totally closed having large windows and balconies facing street in first and second floors. This is due to use of cross ventilation in rooms to decrease humidity. The difference between the courtyards of this region and the ones in hot and arid regions of Iran is the size and location of windows and porticos ${ }^{43}$. In each side of Bushehr houses, especially on first and second floor symmetrical setting of windows can be seen.

Arched roofs are not current in this region and most roofs are flat. In hot weather residents sleep on roof tops at nights and Roofs' walls are mostly latticed to keep the privacy of the residents and at the same time to use air draught. Rooms are situated in wind direction with two sets of windows in different sides to provide expected air draught and because of high humidity they have higher height ${ }^{44}$.

\section{Sahnbedi Neighbourhood}

Shanbedi is one of the oldest and biggest neighbourhoods in Bushehr city with houses, commercial and religious centres with rich architecture ${ }^{45}$. The boundaries of the neighbourhood were as follows: sea from east, Ghabri mosque from north, Kazemi Street from south, and the main gate from Gheblah Side to Haj Hossein and Kazeruni Baraheh ${ }^{46}$.

After immigration of Al-Osfoor family from Bahrein to Bushehr that took place in Ghajarid era and growth of this family this neighbourhood was named after their grandfather (Sheikh Shanbeh) and was called Shanbedi. Also after immigration of wealthy people from Kazerun city, this neighbourhood became one of the luxurious neighbourhoods of this city at that time. One of the characteristics of this neighbourhood is the location of Bazaar that absorbed a lot of visitors in the city. It also had four famous mosques; Jome' (the oldest mosque of Bushehr), Malek and Ghassabha mosque, some
Hosseiniyes, Church (Aramane Garigoori) and religious place (Abbas-Ebn-e Ali Ghadamgah) that is respected by Bushher residents ${ }^{47}$. There are 469 dwellings and 53 shops in this neighborhood ${ }^{48}$.

\section{Kazeruni Barheh (Hosseiniye)}

There is not a complete work done on Bushehr province Hosseiniye. Barheh means an open ground that mourning ceremony took place in it like Sheikh Lotfollah Barheh in Bushehr city that is part of Enghelab Avenue now or Haji yuosef Kalantar Barheh that was named after him. In dayyer province Hosseiniye was called "Matam" like Agha Matam, Haj Abdollah Matam, Sheikh Ahmad and Mir mohammad that had more history in Dayyer port.

As discussed by Sadidol-saltane in Shanbedi neighborhood there are five Hosseiyniye called Sekanche, Mir Abdoh, Kazeruni, Sheikh Zeifollah, Majlesi emam Jome'. In Behbahani Neighbourhood there is a Seyed Abdol Reza and Tagh Seyyed Ne'matollah Hosseyniey. In Dehdashti Neighbourhood there are four mosques and one Hosseiyniye. Pirezan or Fatemeh Zahra Hosseiyniye that it was built by Khazar Kahn Tangestani's mother ${ }^{49}$.

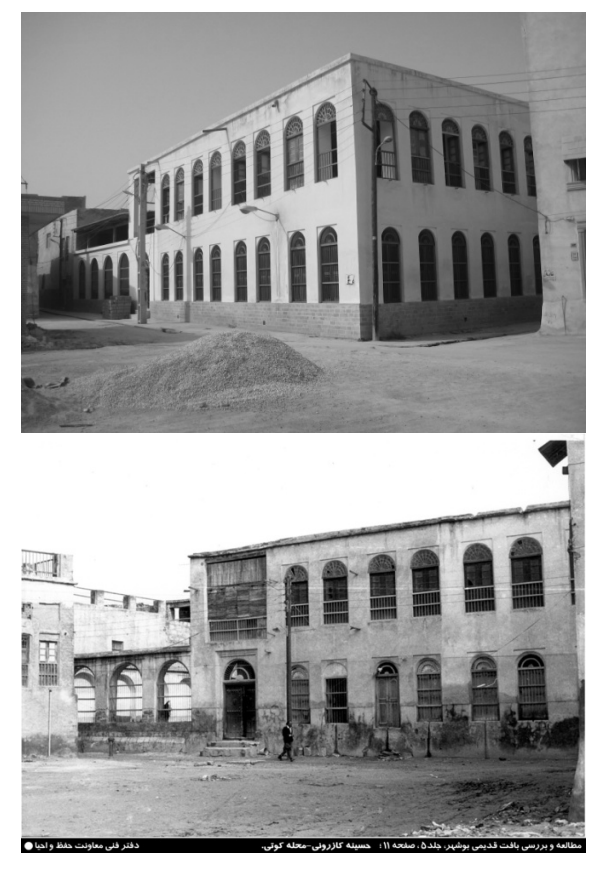

Figure 1. Old and new exterior view of Kazerouni Barheh

Barheh, Baraheh or Hosseiniye was a gathering place for religious ceremonies ${ }^{50}$. Kazeruni Barheh was one of buildings built by Seyyed Mohammad Reza Kazeruni in 1902 in two floors with approximate area of 1000 square meters. Shanbedi mosque that is one of the main mosques of Bushehr city was built at 
the same time by the same builder. Barheh means a building in the way of breeze and it really suits this building and because it is built for moaning and religious purpose it is also called Hosseyniye ${ }^{51}$. This ceremony also took place in mosques like Delgosha, Sheikh Sa'doon and Dehdashti in Bushehr city. This Barhe was renovated in 2010 and is currently used for some religious ceremonies ${ }^{52}$.

\section{Visibility Analysis of the Case Study}

The line graphs show isovist indexes in six different spaces of Kazeruni Barheh. The data of houses show that although the compactness measure for gathering spaces are lower, the circularity is somewhat higher, meaning that these spaces are well connected even though they might seem less compact.

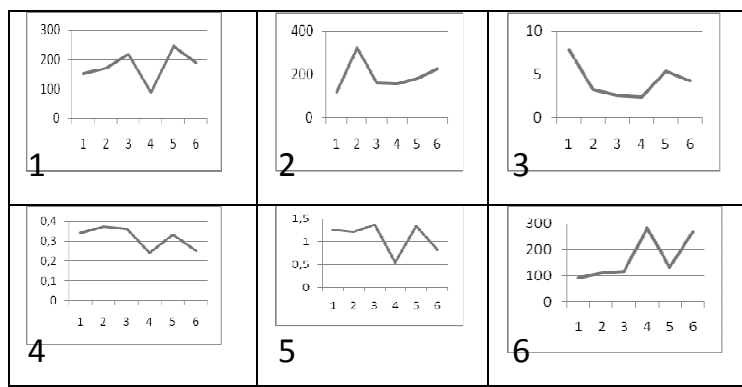

Figure 2. graphs of isovist indexes 1-Area, 2-Perimeter, 3-Drift, 4-Occlusivity, 5-Compactness, 6-Circularityfor related isovist values from the spaces in the Kazeruni

Barheh, generated at the center of spaces using Syntax2D

It is seen from the chart that occlusivity measure is high for most of spaces like Porticos, courtyard and the entrance since they are integrated. Gathering spaces on both ground and first have the highest circularity index. The study shows that area and perimeter indexes are higher for porticos, one for the ground floor and the other for the first floor among the other spaces which have great circulation roles. Drift measure is highest for entrance and the study shows that compactness value for the central courtyard has a tendency to increase among the other spaces.

The area index increases slightly entering the hosseiniye and reaching the courtyard. While it drops dramatically reaching the ground floor gathering space. Getting to the first floor it shows significant increase, peaking at Taremeh (Portico). Compactness and occlusivity indexes show high correlation with this index. According to the parameter line graph, the entrance shows the lowest, while ground floor portico has the highest measure. The rest of places increase slightly reaching from courtyard to the first floor gathering area. Turning to drift index it reveals less correlation with circularity index; in a way that it shows considerable decrease passing from entrance to courtyard. To sum up, ground floor gathering space has the lowest visibility, while portico shows the highest. Courtyard also has the highest compactness index, while first floor portico shows the highest area index.

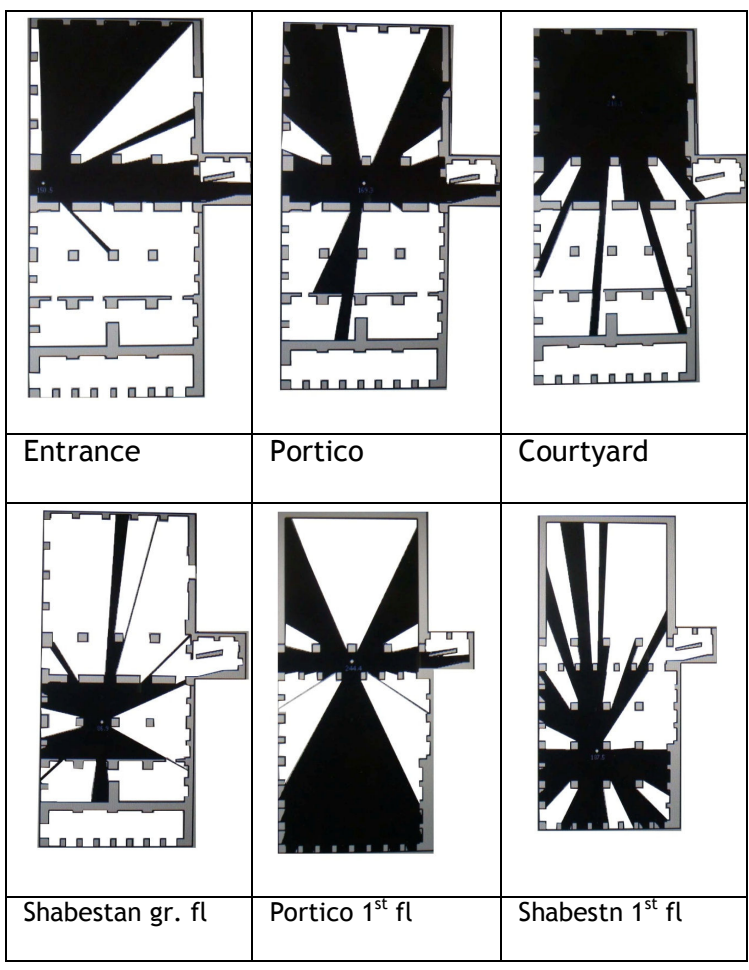

Figure 3. Isovists at the centre of different spaces in the studied building

\section{Conclusion}

To conclude, this study has analyzed visibility of one of the Bushehr city religious spaces with Syntax2D tool. The visibility analysis shows the most integrated space is the portico as many activities take place in it. On the other hand, this space courtyard and room on ground floor are similar in visual integration. While Central courtyard becomes more integrated, gathering space becomes more segregated. Gathering space is the most segregated space according to most measures.

According to the analysis, for larger spaces the boundaries of spaces should be controlled by doors due to the concentration of the plan with the courtyard. This analysis has been accomplished by locating the observer at the center of spaces. On the other hand using other software in this area such as Depthmap software can help finding results. For further studies analyzing more religious spaces in this zone can lead to a better understanding of 
visibility and also comparative study between these religious spaces and other cities buildings with similar use can lead to perceptible findings.

\section{Reference}

1 M. L. Benedikt. 1979. To Take Hold of Space: Isovist and Isovist Fields. Environment and Planning B. 6(1). pp. 47-65

2 M. L. Benedikt. 1979. To take hold of space: isovist and isovist fields. Environment and Planning B. 6(1). pp. 47-65

3 L. S. Davis \& M. L. Benedikt. 1979. Computational Models of Space: Isovists and Isovist Fields. Journal of Computer Graphics and Image Processing, 11 (1). pp. 49-72

4 T. Dong, M. Hanratty, A. Torres \& L. Xu. 2008. Syntax2d Vocabulary Analysis. Michigan: Taubman College of Architecture \& Urban Planning, University of Michigan

5 J. J. Gibson. 1986. The Ecological Approach to Visual Perception. New Jersey: Lawrence Erlbaum Associates Inc.

6 J. J. Gibson. 1986.. The Ecological Approach to Visual Perception. New Jersey: Lawrence Erlbaum Associates Inc.

7 M. L. Benedikt. 1979. To Take Hold of Space: Isovist and Isovist Fields. Environment and Planning B. 6(1). pp. 47-65

8 M. L. Benedikt. 1979. To Take Hold of Space: Isovist and Isovist Fields. Environment and Planning B. 6(1). pp. 52

9 J. Hanson. 1999. Decoding Homes and Houses. Cambridge: Cambridge University Press Hillier B. \& Hanson J. 1984. The Social Logic of Space. Cambridge: Cambridge University press. Hillier J. 1996. Space is the Machine. London: Cambridge University Press

10 T. Meilinger, G. Franz \& H.H. Bülthoff. 2009. From Isovists via Mental Representations to Behaviour: First Steps Toward Closing the Causal Chain. Environment and Planning B: Planning and Design, advance online publication, doi: 10.1068/b34048t

11 J. Peponis, J. Wineman, M. Rashid, S. H. Kim \& S. Bafna. 1997. On the Description of Shape and Spatial Configuration Inside Buildings: Convex Partitions and Their Local Properties. Environment and Planning (B), Planning and Design, 24. pp. 761-781

12 J. Peponis, J. Wineman, M. Rashid, S.H. Kim \& S. Bafna. 1997. On the Description of Shape and Spatial Configuration Inside Buildings: Convex Partitions and Their Local Properties. Environment and Planning (B), Planning and Design, 24. pp. 761-781

13 K. Lynch. 1960. The Image of the City. MA: MIT Press

14 D. Conroy \& S. Bafna. 2003. The Syntactical Image of the City: A Reciprocal Definition of Spatial Elements and Spatial Syntaxes. London: $4^{\text {th }}$ Space Syntax International Symposium
15 M. Turner, D. Doxa \& A. Penn. 2001. From Isovist to Visibility Graphs: A Methodology for the Analysis of Architectural Space. Environment and Planning B: Planning and Design, 28. pp. 103-121

16 M. Batty. 2001. Exploring Isovist Fields: Space and Shape in Architectural and Urban Morphology. Environment and Planning B: Planning and Design. 28. pp. 123-150

P.P. Yang, S.Y. Putra, \& W. Li. 2005. Impacts of Density and Typology on Design Strategies and Perceptual Quality of Urban Space. Jakarta: Map Asia Conference

17 J.J. Gibson. 1986. The Ecological Approach to Visual Perception. New Jersey: Lawrence Erlbaum Associates Inc.

18 P.P. Yang, S.Y. Putra, \& W. Li. 2005. Impacts of Density and Typology on Design Strategies and Perceptual Quality of Urban Space. Jakarta: Map Asia Conference

19 S.Y. Putra \& P. Yang. 2005. Analyzing Mental Geography of Residential Environment in Singapore Using GIS-based 3D Visibility Analysis. Delft: Doing, Thinking, Feeling Home Conference

20 B. Taher \& F. Brown. 2003. The Visibility Graph: An Approach For the Analysis of Traditional Domestic M'Zabite Spaces. London: $4^{\text {th }}$ International Space Syntax Symposium

21 J. Hanson. 1998. Decoding Homes and Houses. Cambridge: Cambridge University Press

22 Turner A. 2003. Analyzing the Visual Dynamics of Spatial Morphology. Environment and Planning B: Planning and Design, 30. pp. 657-656

23 Y.I. Guney. 2007. Analyzing Visibility Structures in Turkish Domestic Spaces. Istanbul: $6^{\text {th }}$ International Space Symposium. pp. 2-3

24 M. Batty. 2001. Exploring Isovist Fields: Space and Shape in Architectural and Urban Morphology. Environment and Planning B: Planning and Design. 28. pp. 123-150

25 S.Y. Putra \& P. Yang. 2005. Analyzing Mental Geography of Residential Environment in Singapore using GIS-based 3D Visibility Analysis. Delft: Doing, Thinking, Feeling Home Conference

26 M. Darvishi. 2003. Bushehr City Hall. Tehran: Masters Thesis, Shahid Beheshti University

27 F. Parsaii. 1995. Traditional Architecture Principals in Today Bushehr Housing Design. Tehran: Masters Thesis. Shahid Beheshti University

28 I. Nabipur. 2006. Bushehr Architecture: Color, Wind and Light symphony. Bushehr: Bonyad Iran

29 S.R. Kashuk. 2005. Glory of Abushahr. Bushehr: Shorou

30 N. Sabatsani. 2007. Bushehr As an Energic City. The Journal of Applied Science, 7, pp. 32623267

31 Wikipedia. 2010. Bushehr, http://en.wikipedia. org/wiki/Bushehr 
32 A.A. Sistani \& A. A. Bushehr. 1990. In a Glance. Tehran: Nasle Danesh

33 S.R. Kashuk. 2005. Glory of Abushahr. Bushehr: Shorou

34 S.R. Kashuk \& G. Thorpe. 2010. The effects of the flow of knowledge and collective intelligence on three centuries of rhizomatic development of Bushehr on the Persian Gulf. Melbourne: Knowledge Cities World Summit

35 Safarnejad, 2008

36 S.R. Kashuk. 2005. Glory of Abushahr. Bushehr: Shorou

37 S.J. Hamidi. 2005. Bushehr Beautiful Province. Bushehr: Shorou

38 A. Kolivand. 2002. Spatial - Structural Characteristics of Bushehr Old Fabric. Abadi 36, pp. $57-60$

39 N. Sha'abani, M. Kuchak Zadeh \& A. Shoeibi. 2007. Old Fabrics Renovation, Establishing Proper Use; Case Study: Old Fabric of Bushehr. Soffe, 45, pp. 54-67

$40 \mathrm{H}$. Anbarani. 1992. Design and Structural Reorganization of Sheikh Sa'sdun Neighbourhood Center. Fine Arts College, Tehran University, pp. 10-15

41 G. Memarian. 1993. Introduction to Residential Architecture of Iran. Tehran: Iran University of Science \& Technology

42 V. Ghobadian. 1994. Climatic Analysis of the Traditional Iranian Buildings. Tehran: Tehran University Publications
43 R.A. Najafabadi, K. Daneshvar, S. Pakseresht \& S. Pooryousefzadeh. 2008. Role of Wind in Vernacular Architecture of $\mathrm{Hot}$ and Humid Region of Iran. Dublin: Dublin Institute of Technology

44 V. Ghobadian. 1994. Climatic Analysis of the Traditional Iranian Buildings. Tehran: Tehran University Publications

45 A. Kanin. 2008. Bushehr Natural and Humane Geography. Tehran: Toloe Danesh

46 J. Kabiri. 1995. Housing Renovation In Old Fabric of Bushehr. Tehran: Shahid Beheshti University

47 A. Kanin. 2008. Bushehr Natural and Humane Geography. Tehran: Toloe Danesh

48 J. Kabiri. 1995. Housing Renovation In Old Fabric of Bushehr. Tehran: Shahid Beheshti University

49 M.A.Kh Sadid ol-Saltaneh Bandarabbasi. 2007. Persian Gulf and Omman Sea Northern Countries. Tehran: Amirkabir

50 0. Zahed. 2011. A Glance To History of Bushehr Hosseiniye. http://www.liravi. mihanblog.com/post/378

51 S.A.H. Kazeruni. 2005. Bushehr, the City of Sun and Sea. Tehran: Liyan

52 0. Zahed. 2011. A Glance To History of Bushehr Hosseiniye. http://www.liravi. mihanblog.com/post/378 